Article

\title{
Calving Fronts of Antarctica: Mapping and Classification
}

\section{Christine Wesche *, Daniela Jansen and Wolfgang Dierking}

Alfred Wegener Institute, Helmholtz Centre for Polar and Marine Research, Bremerhaven, Bussestr. 24, D-27570 Bremerhaven, Germany; E-Mails: daniela.jansen@awi.de (D.J.); wolfgang.dierking@awi.de (W.D.)

* Author to whom correspondence should be addressed; christine.wesche@awi.de; Tel.: +49-471-4831-1870; Fax: +49-471-4831-1797.

Received: 25 September 2013; in revised form: 6 November 2013 / Accepted: 7 November 2013 / Published: 25 November 2013

\begin{abstract}
Antarctica is surrounded by a variety of large, medium and small sized ice shelves, glacier tongues and coastal areas without offshore floating ice masses. We used the mosaic of the Radarsat-1 Antarctica Mapping Project (RAMP) Antarctic Mapping Mission 1 (AMM) to classify the coastline of Antarctica in terms of surface structure patterns close to the calving front. With the aid of an automated edge detection method, complemented by manual control, the surface structures of all ice shelves and glacier tongues around Antarctica were mapped. We found dense and less dense patterns of surface structures unevenly distributed over the ice shelves and ice tongues. Dense surface patterns are frequent on fast flowing ice masses (ice streams), whereas most ice shelves show a dense surface pattern only close to the grounding line. Flow line analyses on ten ice shelves reveal that the time of residence of the ice along a flow path and-associated with it - the healing of surface crevasses can explain the different surface structure distribution close to the grounding line and the calving front on many ice shelves. Based on the surface structures relative to the calving front within a $15 \mathrm{~km}$-wide seaward strip, the ice shelf fronts can be separated into three classes. The resulting map of the classified calving fronts around Antarctica and their description provide a detailed picture of crevasse formation and the observed dominant iceberg shapes.
\end{abstract}

Keywords: ice shelf; edge detection; SAR; icebergs 


\section{Introduction}

Antarctica's ice shelves and glacier tongues are birthplaces for icebergs, which account for a large fraction of the negative term in annual mass balance [1-5]. Ice shelves are fed by the inland ice (draining into coastal embayments through outlet glaciers) and in addition gain mass by snow accumulation [1] and marine ice accretion [6-9]. Large uncertainties exist in calculating the mass loss of the Antarctic ice sheet due to iceberg calving [2] as well as in estimating the freshwater input from the inland ice into the Southern Ocean $[4,5,10,11]$.

Surface structures on the inland ice and the ice shelves as well as calved icebergs can be monitored over large regions using aerial photography and satellite images. An overview of surface structures visible on ice shelves (e.g., crevasses, rifts, pressure ridges, ice dolines, ogives) is given by $[12,13]$. Bottom melt channels and basal crevasses can also be traced at an ice shelf surface [4,14-17]. Since it is often difficult to identify the specific type of a surface structure in the Synthetic Aperture Radar (SAR) images (due to the relatively coarse spatial resolution), we do not distinguish single types explicitly and instead use the generic terms "surface structure" or "surface feature". Glasser and Scambos [13] mapped and classified the surface structures on the Larsen B Ice Shelf using Landsat 7 Enhanced Thematic Mapper Plus (ETM+) and Advanced Spaceborne Thermal Emission and Reflection Radiometer (ASTER) data. Humbert and Steinhage [17], Luckman et al. [15] and McGrath et al. [16] investigated surface structures visible on Fimbul and Larsen C ice shelves, respectively, using radar and optical satellite images complemented by airborne or ground based radar measurements.

In this study we employed SAR imagery to investigate the regionally varying characteristics of surface structures on ice shelves and ice tongues. Our objective is to provide a classification of those structures and to relate iceberg shape and size to the different structure classes. The motivation for the latter is a study by Dowdeswell [18]. He analysed aerial photographs focusing on icebergs calved from glaciers around Svalbard and found that their shapes and sizes are related to glacier dynamics and morphology. For detecting the structures on every ice shelf and tongues around Antarctica we used a mixture of automated and visual pattern recognition approaches. For selected ice shelves, we investigated the link between predominant surface structure density and flow velocity. We confined the classification to an ice shelf or tongue area within $15 \mathrm{~km}$ upstream of the calving front, as our main interest is focused on calving processes. We separated the Antarctic coastline into segments based on the pattern of the surface structures and determined the dominant iceberg shapes for the different coastline segments. The separation of the coastline into different calving front classes may provide useful hints about the local ice dynamics, and in combination with their associated iceberg shapes, confines the number of potential locations from where an iceberg originates and therefore improves the estimation of iceberg mass.

\section{Data and Methods}

\subsection{Data Sets}

The automated detection of surface structures was applied to the image mosaic of the Radarsat-1 Antarctic Mapping Project Antarctic Mapping Mission 1 (RAMP AMM-1). The mosaic is a composition of more than 3,000 Radarsat-1 SAR images covering the entire Antarctic continent and the surrounding 
ocean. The AMM-1 was carried out over a two month period from September to October 1997 [19]. Thus, the mosaic shows regional snapshots of ice conditions in this particular period. The data set is distributed by the Byrd Polar Research Center at the Ohio State University in Columbus, Ohio (http://bprc.osu.edu/rsl/radarsat/data/).

In this study we used the $100 \mathrm{~m}$ pixel size imagery as a compromise between magnitude of speckle and spatial resolution. Speckle, a grainy pattern in SAR images caused by random interferences of the scattered radar waves within a resolution cell [20], affects the detection of surface structures. Its magnitude can be reduced by averaging neighboring pixels. The product we use ( $100 \mathrm{~m}$ pixel size) is provided as a result of resampling data with a pixel size of $25 \mathrm{~m}$, so that speckle sufficiently reduced (http://bprc.osu.edu/rsl/radarsat/data/). The data set is provided in a 16-bit format which contains backscatter coefficients in decibel $(\mathrm{dB})$. To simplify the surface pattern detection, we converted the backscattering coefficients back to linear scale.

\subsection{Automated Detection of Surface Structures}

The automated detection of surface structures using the RAMP AMM-1 SAR image mosaic is based on an edge detection method (sigma-on-mu) described by Septhon et al. [21] and Young et al. [22]. The floating ice masses (shelves and tongues) were extracted automatically using the MOA grounding line [23] and the coastline of the RAMP AMM-1 project (http://bprc.osu.edu/rsl/radarsat/data). We identified 183 ice shelves and glacier tongues with areas between 20 and about 490,000 $\mathrm{km}^{2}$ for the Ross Ice Shelf. Ice shelves and ice tongues smaller than $20 \mathrm{~km}^{2}$ were neglected in this study (comprising $0.16 \%$ of total ice-shelf area), because a reliable feature detection on these small areas was not possible. A detailed look at the radar image mosaic shows sharp drops of the radar intensity at the boundary between adjacent SAR scenes at several sites, where the mean backscattering coefficients differ by up to $2 \mathrm{~dB}$. These transitions might be caused by changing environmental conditions during the acquisition period, as a small amount of liquid water in the upper layer increases the absorption of the radar signal significantly, which in turn decreases the backscattering coefficient [24]. However, European Centre for Medium-Range Weather Forecasts (ECMWF) daily temperature data (http://data-portal.ecmwf.int/data/d/interim_daily/, 2-m above surface) for September and October 1997 do not indicate melting conditions on any ice shelf. Another parameter directly influencing the backscatter intensity is the incidence angle of the radar signal. Wesche and Dierking [25] showed that an incidence angle varying in the range between 20 to $40^{\circ}$ has an effect on the backscattering intensity of icebergs with possible drops of 3-6 dB (see [25]). In the data collection used for this study, radar incidence angles on the ice shelves vary between $22^{\circ}$ and $31^{\circ}$. In the absence of any temperature effects we therefore assume that the sharp intensity transitions are caused by the different incidence angles.

Surface structures in the SAR images are recognized as rapid changes of the backscattering coefficient within a short distance (neighboring image pixels). Thus, the detectability of surface structures is influenced by the pixel size (in our case $100 \times 100 \mathrm{~m}$ ) and by the presence of speckle. In general, only structures which are at least as wide as the pixel size or which reveal a large intensity contrast to the adjacent undisturbed surface areas can be recognized. To reduce the influence of speckle on the detection 
result, we applied an enhanced Lee filter [26] with a kernel of $3 \times 3$ pixels. After filtering the speckle is reduced, while the texture of the images is preserved [26]. We employed mean $(\mu)$ and standard deviation $(\sigma)$ of the backscattering intensity to separate homogeneous from inhomogeneous areas in the image. Both parameters were determined within a moving $3 \times 3$ pixel window. Using the resulting images of the mean and standard deviation, the sigma-on-mu $\left(\frac{\sigma}{\mu}\right)$ values were calculated pixel-by-pixel. Large $\frac{\sigma}{\mu}$-ratios indicate areas of rapidly changing backscattering coefficients, which are then interpreted as edges.

To fix the thresholds of the $\frac{\sigma}{\mu}$-ratios for automatically separating ice structures from undisturbed surface areas, we generated a reference data set by manually placing regions of interests (ROIs) on the boundaries of selected visible surface structures. These structures appear in most cases as linear patterns. The thresholds are obtained by comparing the $\frac{\sigma}{\mu}$-ratios of the structures (obtained from the ROIs) and of the undisturbed surface areas in between. To consider the effect of the radar incidence angle, $\frac{\sigma}{\mu}$-thresholds were determined separately for different incidence angle ranges.

By investigating the radar intensity variations along the coastlines in detail, we found that the backscattering contrast between surface features and undisturbed ice varied significantly, independent of the incidence angle. Hence we defined three thresholds using the median (second quantile), the third quantile and the ninths percentile of the cumulative frequency distributions of the $\frac{\sigma}{\mu}$-values obtained from the ROIs. The surface structure detection results obtained with all three thresholds were then visually inspected. The median threshold showed optimal performance in areas with high contrasts, the ninth percentile in areas with low contrasts and the third quantile was used in areas of moderate intensity contrasts. On 42 small ice shelves, with areas between 20 and $327 \mathrm{~km}^{2}$, the contrasts were too low to identify any structures. The detection results for the other ice shelves were converted to polygon style features indicating the location of a surface structure such as crevasse, rift or surface depression. The overall performance of the detection was tested by using a reference data set generated by manual identification of all surface structures on the Shackleton Ice Shelf as test site. As a quality criterion for the automated structure identification we compared the total length of the automatically detected linear structures $(2,797 \mathrm{~km})$ to the total length of the visually delineated structures $(4,372 \mathrm{~km})$. The result is a mean detection performance of $64 \%$ for the test site (Figure 1).

The result of the detection performance is very similar to the ones presented by [27] and [22]. Both presented iceberg detection algorithms using thresholding and the sigma-on-mu, respectively, with variable detection performances [22,27]. Our detection performance can be traced back to the application of the enhanced Lee filter, which causes the radar intensity variations in the SAR scene to become smoother and the contrast between homogeneous and heterogeneous areas to become lower. Some surface structures appeared blurred after filtering and were therefore invisible for the our method.

To minimize false detections (Figure 1b), we removed all identified structures that consisted of less than 10 pixels or $0.1 \mathrm{~km}^{2}$. Some automatically detected structures around islands and close to the grounding line, where closely spaced structures were merged to one large patch in the radar image, could not be identified by visual inspection of the Radarsat-1 mosaic. High resolution Landsat-7 imagery of a part of the Shackleton Ice Shelf (not shown) resolves the dense pattern of surface structures. This means that not all features that do not match the visually determined reference data set are false detections. 
Figure 1. Performance of the automated structure detection on the northern part of the Shackleton Ice Shelf. The blue lines in panel (a) show the automatically detected features that match the visually detected features. Red lines indicate where the automated detection failed. A combination of both (red and blue) shows all visually detected surface structures. In panel (b) all automatically identified structures including false detection results (blue areas) are compared with the visually detected surface structures (red lines). The grounding line and coastline as well as the islands (all grey) are taken from Haran et al. [23].

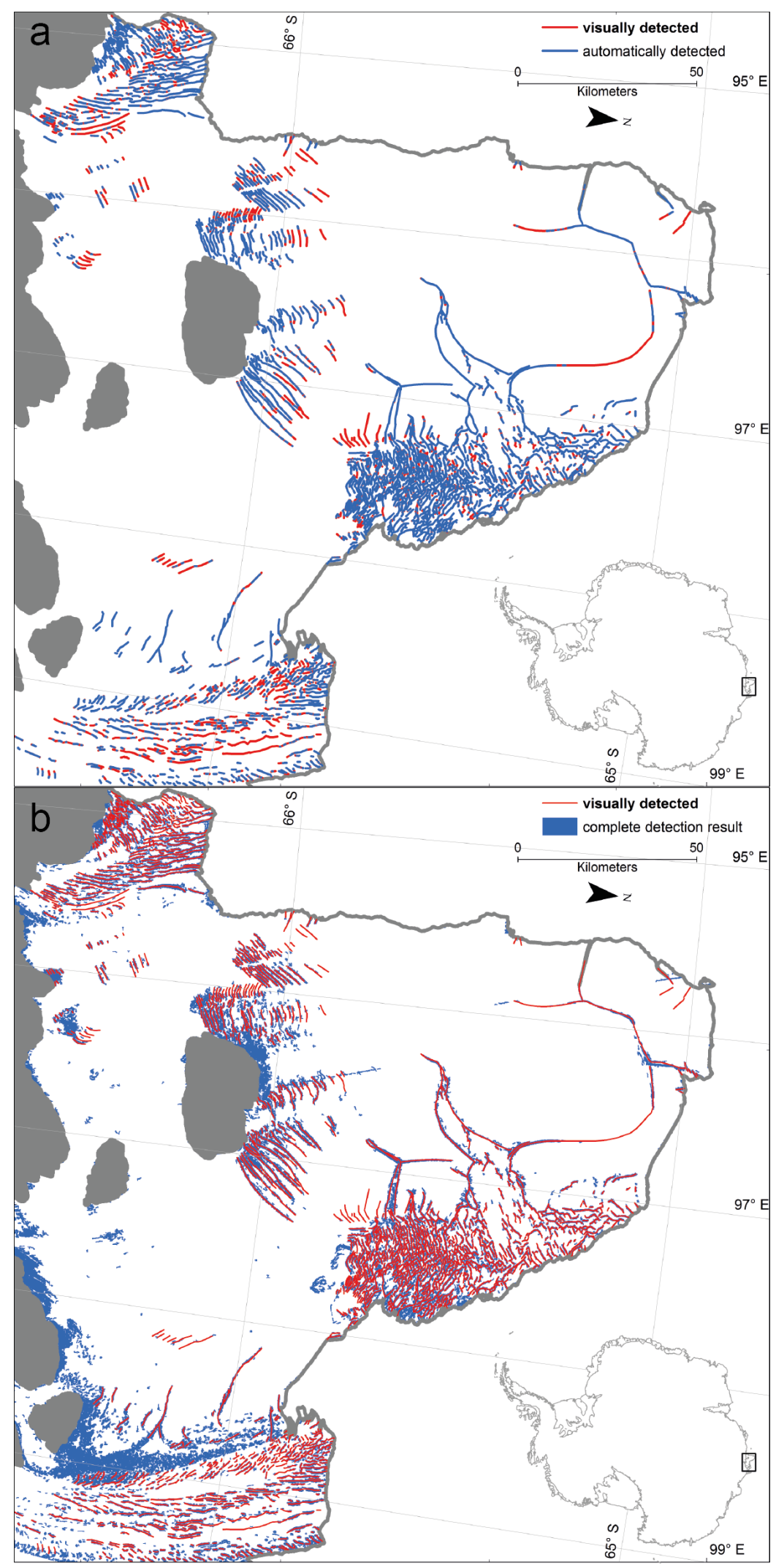


Considering the problems with the performance of the automated detection, we used the result as starting point for a thorough visual identification of surface structures along the entire ice shelf margins within a $15 \mathrm{~km}$ wide strip inland. Although the visual detection was rather time-consuming, it was nevertheless important for generating a reliable data base for further analyses. Taking into account that the size of calving icebergs is limited by the crevasses spacing at the surface close to the front of the parent ice shelf [18], we fixed the width of the strip for inspection to $15 \mathrm{~km}$ from the calving front as a compromise between the width of the largest iceberg observed by remote sensing techniques (B15: $37 \mathrm{~km}$ [28]) and the extent of smaller ice shelves.

\section{Results and Discussion}

\subsection{Surface Structure Distribution}

The surface characteristics of ice shelves and tongues change in many cases from denser patterns (i.e., single crevasses or depressions are more closely spaced) closer to the grounding zone to a smooth surface at the ice front. This was also found by Glasser and Scambos [13] on the Larsen B Ice Shelf. Many of the surface structures have their origin at the grounding line, where the ice is subject to high bending and shear stresses [13]. The difference in surface structure density along flow can be explained by the healing process of the crevasses [29], which starts as soon as the stresses decrease along the flow path. The healing process is supported by further accumulation of snow along the flow path. Therefore we assume that the longer the residence time of the ice on the floating ice shelf the more advanced is the healing process. To assess the validity of this assumption, we investigated the time of residence (TOR) of an ice volume along several flow paths (flow lines) on ten selected ice shelves and ice tongues. The ten ice shelves represent the surface structure classes. Brunt and Shackleton ice shelves are regions where we found both dense and less dense surface structures. Mertz and Drygalski ice tongues show very densely spaced surface patterns over their entire area. The Amery Ice Shelf and the outflow of the Jutulstraumen Glacier (Trolltunga, a part of the Fimbul Ice Shelf) are intersected by large structures orthogonal to the calving front. The Ekström Ice Shelf, on which the German overwintering station Neumayer III is located, is moving very slowly $(\sim 200 \mathrm{~m} / \mathrm{a}$ [30,31]). This ice shelf is characterized by a less dense surface structure distribution. The three largest ice shelves (Ross Ice Shelf, Filchner-Ronne Ice Shelf and Larsen C Ice Shelf) were also investigated. To calculate the flow path and the TOR we used velocity vectors based on radar remote sensing [30,31]. For each ice shelf/ tongue we chose flow line starting points mainly at feeding glaciers and calculated the corresponding flow lines starting at the grounding line. An example of flow lines on the Shackleton Ice Shelf is shown in Figure 2.

We were mainly interested in the differences of residence times dependent on the density of surface patterns on the $15 \mathrm{~km}$ strip along the ice front. In case of very dense patterns we found that the ice needs between 78 and 968 years to move from the grounding line to the ice front. For less dense patterns we obtained a range between 140 and 2,764 years. This suggests that dense patterns mainly exist on faster flowing ice shelves/ice tongues. The longer the ice moves in an undisturbed flow regime, the more probable is that crevasses, which are present close to the grounding line, seal on their way to the ice front due to healing processes. 
Crevasses and depressions may also become invisible in radar images because of snow accumulation. The surface mass balance (SMB) increases from the interior of the ice sheet with desert like conditions (SMB $<25 \mathrm{~mm}$ w.e. $\mathrm{a}^{-1}$ ) to the coastal areas with high-accumulation rates $\left(\mathrm{SMB}>500 \mathrm{~mm}\right.$ w.e. $\left.\mathrm{a}^{-1}\right)[32]$.

Figure 2. Map of Shackleton Ice Shelf. The background colors are flow velocities [31]. The bold black lines show the positions of the calculated flow lines and the arrows the direction of the flow. The grey areas represent the grounded portions (e.g., islands, inland ice), which were taken from Haran et al. [23].

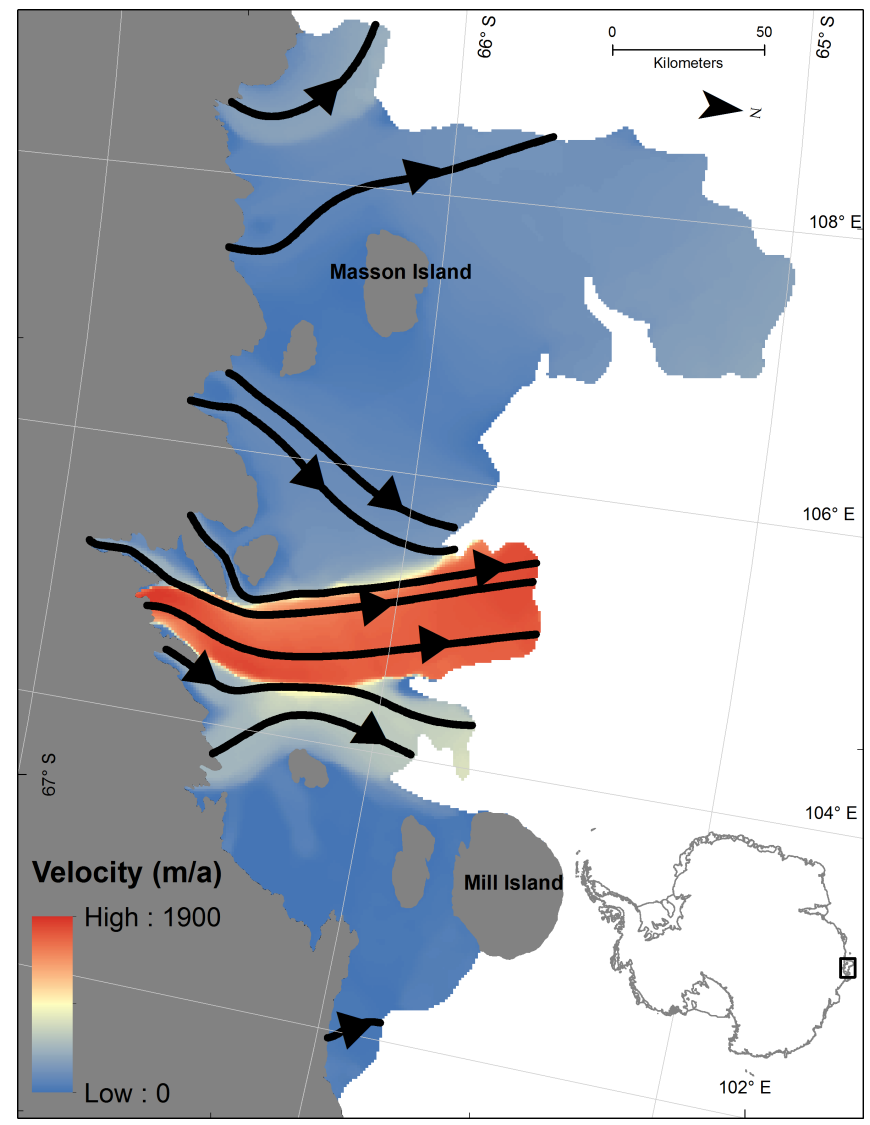

\subsection{Classification of Surface Features}

We assume that the surface structure pattern typical for a given part of the coastline constrain geometrical properties of icebergs that potentially calve thereof. Additionally, we assume the ice shelves to be in balance. We separated the detected surface structures into three groups based on their orientation relative to the mean stable calving front: (1) parallel, (2) orthogonal, and (3) a combination of (1) and (2). Class 3 is a typical surface structure of ice streams and will be referred to as ice stream (IS) pattern. In the following part we briefly describe the three classes:

1. Surface structures parallel to the calving front $(C 1)$ : Surface structures parallel to the calving front are typically formed by rifts, crevasses, pressure ridges or depressions. The latter indicate the existence of basal crevasses [15-17]. Surface depressions are visible in SAR and optical images as sometimes quasi-periodic patterns. Ice shelf rifts propagate through the entire thickness of the 
ice shelf and can be several hundred kilometers in length and several kilometers in width. They may arise from basal or surface crevasses $[13,28]$ and often originate due to obstacles to the ice flow as ice rises or ice rumples. An example of parallel surface structures is presented in Figure 3.

Figure 3. Map of parallel structures on Jelbart Ice Shelf front. In the upper left corner of the figure the location of the Jelbart Ice Shelf is shown. The grey lines represent the coastline taken from RAMP AMM-1 (http://bprc.osu.edu/rsl/radarsat/data/) and the grounded ice (grey areas) are taken from Haran et al. [23].

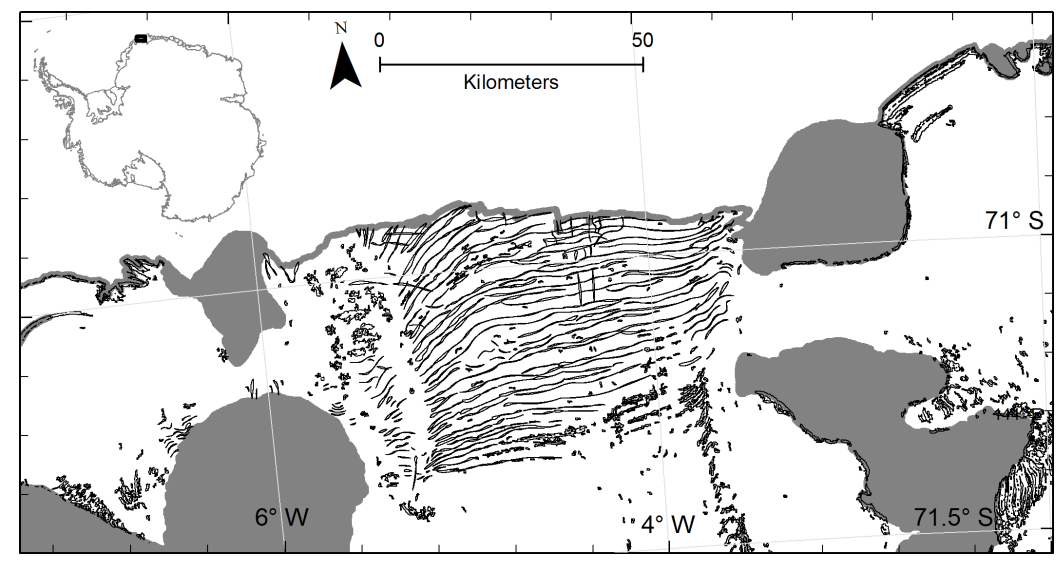

2. Surface structures orthogonal to the calving front $(C 2)$ : These structures are rifts cut back into the ice shelf from the calving front into the ice shelf (Figure 4; [13,33]). They open due to the gravitational side-ward spreading (radially diverging ice flow) of the ice shelf, when its sides are no longer buttressed by land [34]. Wind speed, tidal amplitude and ocean swell drive the propagation of rifts from the ice edge into the interior of the ice shelves [35]. An example is the "loose-tooth" rift system at the Amery Ice Shelf front [35] or the rifts in the central part of the ice front at Filcher-Ronne Ice Shelf (Figure 4).

Figure 4. Map of orthogonal structures on Ronne Ice Shelf front. In the lower left corner of the figure the location of the Ronne Ice Shelf is shown. The grey lines represent the coastline taken from RAMP AMM-1 (http://bprc.osu.edu/rsl/radarsat/data/) and the grounding line taken from Haran et al. [23].

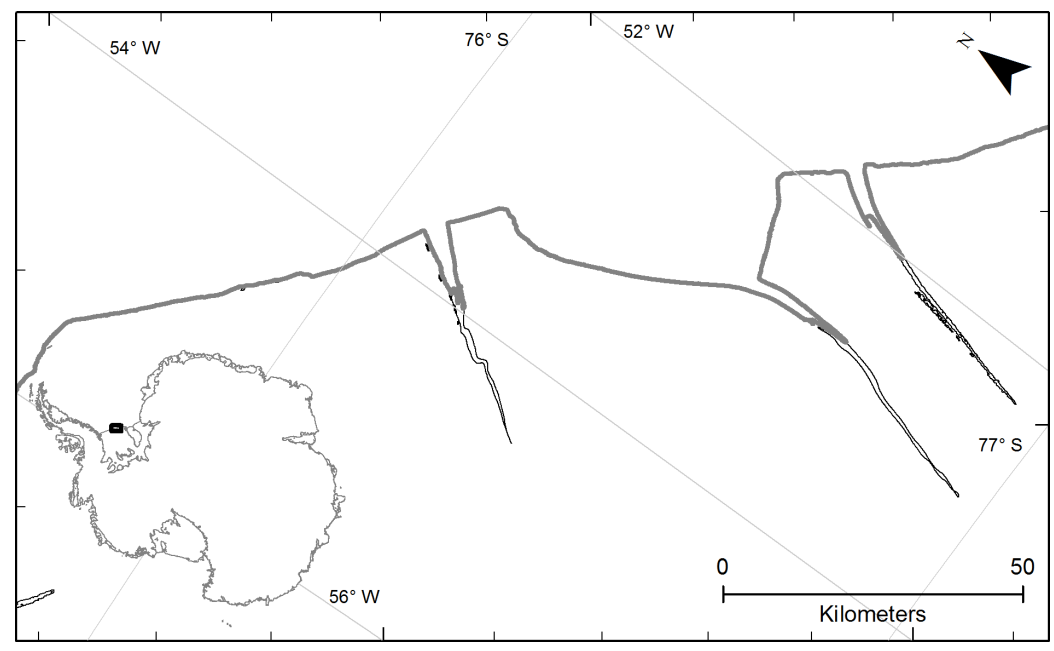


3. IS pattern (C3): The IS pattern can be found on fast flowing glacier tongues like those of the Mertz or Ninnis Glaciers (Figure 5), or very small ice shelves, where the TOR is not sufficient for a crevasse healing process (see above). Thus, longitudinal and transversal crevasses originating close to the grounding line [13] are still visible at the ice edge.

Figure 5. Map of detected surface structures on the Mertz and Ninnis Glacier Tongues. The grey lines represent the coastline taken from RAMP AMM-1 (http://bprc.osu.edu/rsl/radarsat/data/) and the grounding line taken from Haran et al. [23]. The grounded portion of the ice sheet in presented as grey area.

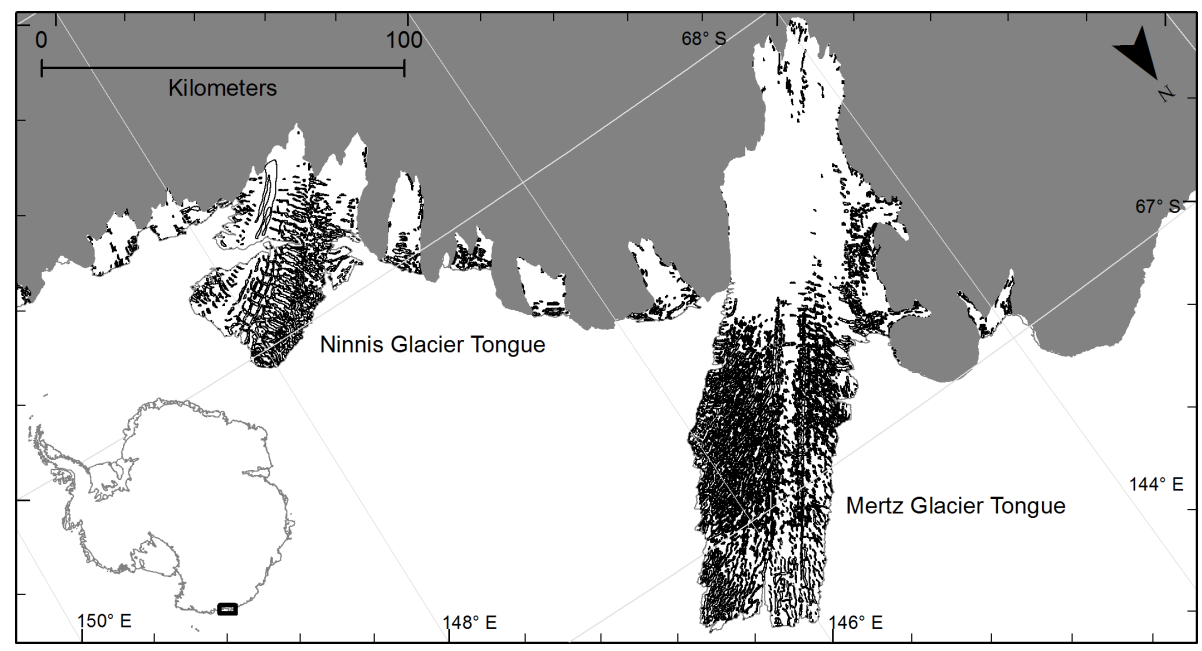

We divided the coastline of Antarctica into segments based on the three pattern classes described above by visual inspection. For a complete classification of surface structure variations along the coastline we additionally had to consider segments where no crevasses are visible within the frontal $15 \mathrm{~km}$-zone or where the ice is grounded. Grounded ice comprises 39.8\% of the total coastline length of Antarctica (C5 in Figure 6). Parallel crevasses (C1) can be found along segments summing up to $28 \%$ of the coastline length, orthogonal crevasses (C2) along 9.1\%, and IS patterns (C3) along 15.7\%. In the remaining $7.4 \%$ we could not identify any surface structures in our images ( $\mathrm{C} 4$-Figure 6).

It should be noted, that the front of a single ice shelf often consist of more than one surface structure classes. We checked the calving fronts for these class changes and found that about $64 \%$ of the calving fronts are one-class fronts. A distribution of class changes is presented in Table 1.

Ice margins with all three classes at one calving front can be found on West Ice Shelf, Shackleton Ice Shelf, Totten Glacier and connected ice shelves, Tucker Glacier and Drygalski Glacier Tongue.

We splitted the coastline into four sectors using the iceberg naming strategy of the National Ice Center (http://www.natice.noaa.gov/—sector $\mathrm{A}=0^{\circ}$ to $-90^{\circ}$ longitude, sector $\mathrm{B}=-90^{\circ}$ to $180^{\circ}$ longitude, sector $\mathrm{C}=180^{\circ}$ to $90^{\circ}$ longitude and sector $\mathrm{D}=90^{\circ}$ to $0^{\circ}$ longitude). The amount of coastline classes within the sectors is given in Table 2 . 
Figure 6. Coastline map with different colors showing different classes. $\mathrm{C} 1=$ parallel surface structures, C2 = orthogonal surface structures, C3 = IS pattern, C4 = no crevasses, $\mathrm{C} 5=$ grounded ice. The percentages given in brackets give the portion of the class relative the the total length of the coastline. The numbers around the coastline show locations mentioned in the text (please see text). Grounding line (grey) taken from Haran et al. [23].

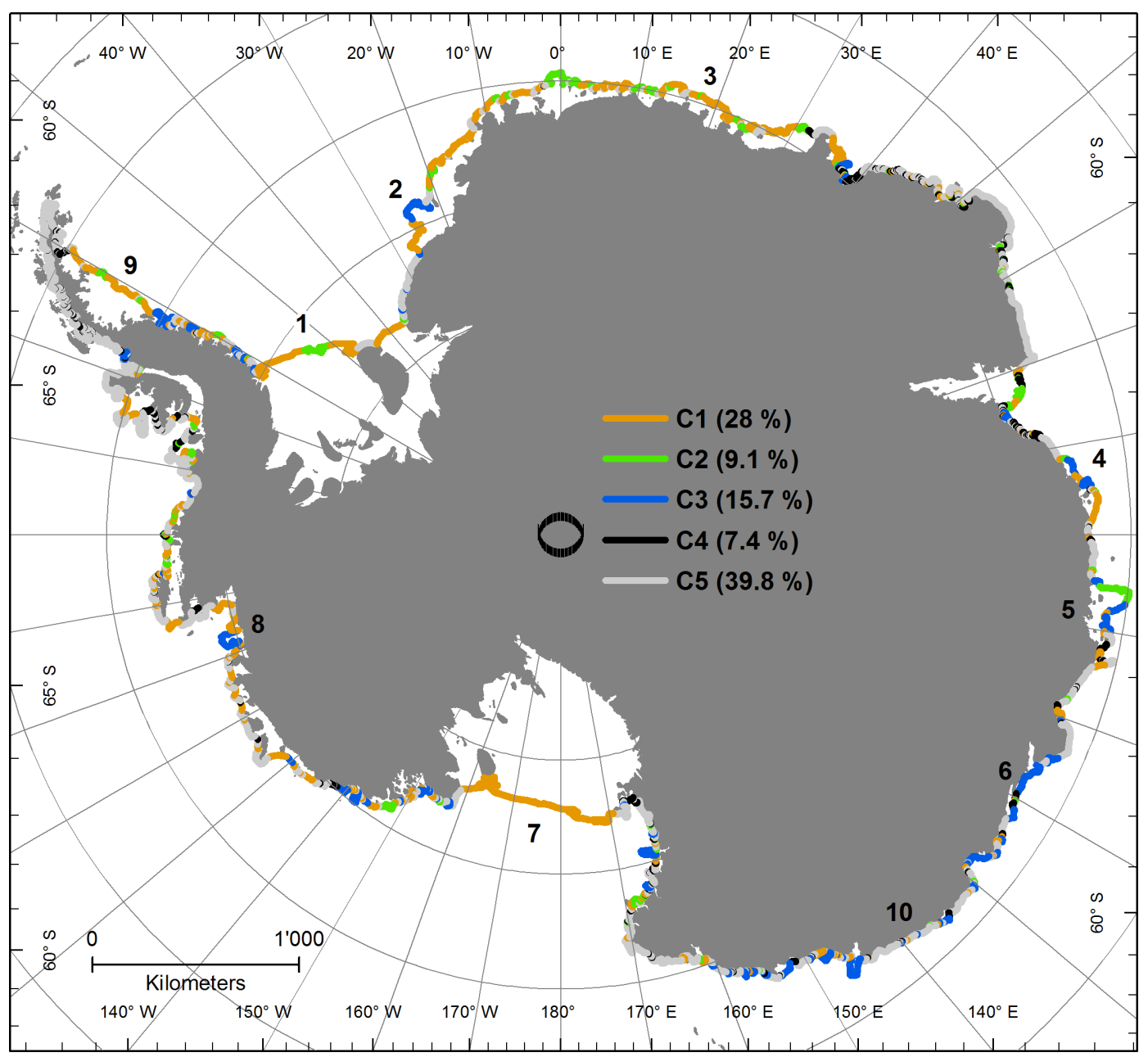

Table 1. Class-change distribution along the calving fronts $(\mathrm{C} 1=$ parallel surface structures, $\mathrm{C} 2=$ orthogonal surface structures, C3 = IS pattern and C4 = no crevasses).

\begin{tabular}{cc}
\hline Class Combination & Amount \\
\hline single class & 138 \\
$\mathrm{C} 1+\mathrm{C} 2$ & 34 \\
$\mathrm{C} 1+\mathrm{C} 3$ & 12 \\
$\mathrm{C} 1+\mathrm{C} 4$ & 15 \\
$\mathrm{C} 2+\mathrm{C} 3$ & 5 \\
$\mathrm{C} 2+\mathrm{C} 4$ & 2 \\
$\mathrm{C} 3+\mathrm{C} 4$ & 6 \\
$\mathrm{C} 1+\mathrm{C} 2+\mathrm{C} 3$ & 5 \\
\hline
\end{tabular}


Table 2. Distribution of coastline classes $(\mathrm{C} 1=$ parallel surface structures, $\mathrm{C} 2=$ orthogonal surface structures, C3 = IS pattern, C4 = no crevasses, C5 = grounded ice) within four different sectors (see text).

\begin{tabular}{cccc}
\hline Sector & Amount on Total Coastline Length [\%] & Class & Amount [\%] \\
\hline A & 32.5 & C1 & 28.5 \\
& & C2 & 9.8 \\
& & C3 & 9.8 \\
& & C4 & 3.8 \\
& 16.5 & C5 & 48.1 \\
\hline B & & C1 & 46.2 \\
& & C2 & 4.7 \\
& & C3 & 17.2 \\
& & C4 & 2.5 \\
C & 27.7 & C5 & 29.4 \\
\hline & C1 & 21.8 \\
& & C2 & 6.6 \\
& & C3 & 26.7 \\
& & C4 & 6.9 \\
D & 23.3 & C5 & 38.0 \\
& & C1 & 32.5 \\
& & C2 & 14.8 \\
& & C3 & 7.2 \\
& & C4 & 15.2 \\
& & C5 & 30.3 \\
\hline
\end{tabular}

The fractions of coastline classes within the sectors differs. In sector A, the grounded sections (C5) occur most frequently along the coastline, followed by $\mathrm{C} 1$. In sector $\mathrm{B}$, the large fraction of $\mathrm{C} 1$ is mainly concentrated at the Ross Ice Shelf. The distribution of coastlines classes in sector $\mathrm{C}$ changes again, here $\mathrm{C} 1$ and $\mathrm{C} 3$ occur most often. In sector $\mathrm{D}$, the relative portions of $\mathrm{C} 1$ and $\mathrm{C} 5$ are largest, whereas $\mathrm{C} 3$ covers only a small fraction of the coastline.

The width of the ice shelf embayment at the seaward edge limits the size of potential icebergs [18]. In our case, the width is calculated as a straight line between neighboring "pinning points" (e.g., islands and ice rises).

In Table 3, we listed the number of calving fronts with their widths occuring in a given interval for sector A, B, C, and D. The total number of calving fronts (217) differs from the total number of ice shelves (183), because some ice shelves have more than one calving front (e.g., Abbot Ice Shelf). Due to the partition in sectors, the calving fronts at the borders of two sectors were cut and were part of both sectors, e.g., calving front of the Ross Ice Shelf. The widths range from $2.25 \mathrm{~km}$ (ice shelf at Clarie Coast (Figure 6, number 10), west of Mertz Glacier) to $632 \mathrm{~km}$ (Ross Ice Shelf-Figure 6, number 7). Only eight other ice shelves have a continuous calving front wider than $200 \mathrm{~km}$ (Ronne Ice Shelf (number 1), Brunt Ice Shelf (number 2), Roi Baudouin Ice Shelf (number 3), West Ice Shelf (number 4), Shackleton Ice Shelf (number 5), Totten Glacier with connected ice shelves (number 6), Thwaites Glacier ( number 8) and Larsen C Ice Shelf (number 9)-for numbers see Figure 6). At these ice shelves, we can expect the calving of giant icebergs/ ice islands. Smaller icebergs can calve from 
every ice shelf. The largest class are calving front widths of $10-50 \mathrm{~km}$. Almost $77 \%$ of the calving fronts are shorter than $50 \mathrm{~km}$. The distribution within the sectors shows, that the possibility of giant icebergs is given in each sector, whereas the second largest class (100-200 km width) is more frequent in sectors A and D.

Table 3. Widths of calving fronts in the four sectors (see text).

\begin{tabular}{ccc}
\hline Sector & Width $[\mathbf{k m}]$ & Number \\
\hline $\mathbf{A}$ & $<10$ & 3 \\
& $10-50$ & 26 \\
& $50-100$ & 10 \\
& $100-200$ & 6 \\
& $>200$ & 3 \\
\hline $\mathbf{B}$ & $<10$ & 12 \\
& $10-50$ & 26 \\
& $50-100$ & 7 \\
& $100-200$ & 1 \\
& $>200$ & 2 \\
\hline $\mathbf{C}$ & $<10$ & 23 \\
& $10-50$ & 35 \\
& $50-100$ & 8 \\
& $100-200$ & 1 \\
& $>200$ & 3 \\
\hline D & $<10$ & 13 \\
& $10-50$ & 30 \\
& $50-100$ & 2 \\
& $100-200$ & 7 \\
& $>200$ & 2 \\
\hline
\end{tabular}

We noticed that the orientation of crevasses is connected to the geometry of the ice front. We mainly found orthogonal crevasses on calving fronts, which have a convex geometry (meaning that the maximum seaward extent of the ice front lies in front of an imaginary straight line between neighboring pinning points). In contrast, parallel crevasses are found on ice shelves, where the ice front either follows the imaginary straight line between pinning points or exhibit a concave shape.

\subsection{Shapes and Sizes of Potential Icebergs}

It seems reasonable to assume that the orientation of crevasses of the ice shelves influences the shape of icebergs calving from the particular shelf [18]. We studied whether the surface structures along the coastal fronts are in fact a good indicator for iceberg shape. In the following part, we present an overview of the main iceberg shapes for the three calving front patterns.

Figure 7 shows a calving event at the ice front of the Trolltunga (Fimbul Ice Shelf), which is characterized by the presence of orthogonal crevasses. The shape and the size of icebergs calving from such sites are predefined by the distance and the course of the rifts. The iceberg shape observed by remote sensing is often trapezoidal or triangular. Another example of an iceberg originating from an orthogonal crevassed calving front at Amery Ice Shelf is presented by Fricker et al. [36] (see their Figure 4). 
Figure 7. Iceberg calving event at an orthogonal crevassed coastline. The SAR image shows the Trolltunga (Fimbul Ice Shelf). In the upper left the location of this area (yellow rectangle) is indicated. The white lines in the inset image represent the coastline taken from RAMP AMM-1 (http://bprc.osu.edu/rsl/radarsat/data/) and the grounding line taken from Haran et al. [23]. Image courtesy: Byrd Polar Research Center \& CSA.

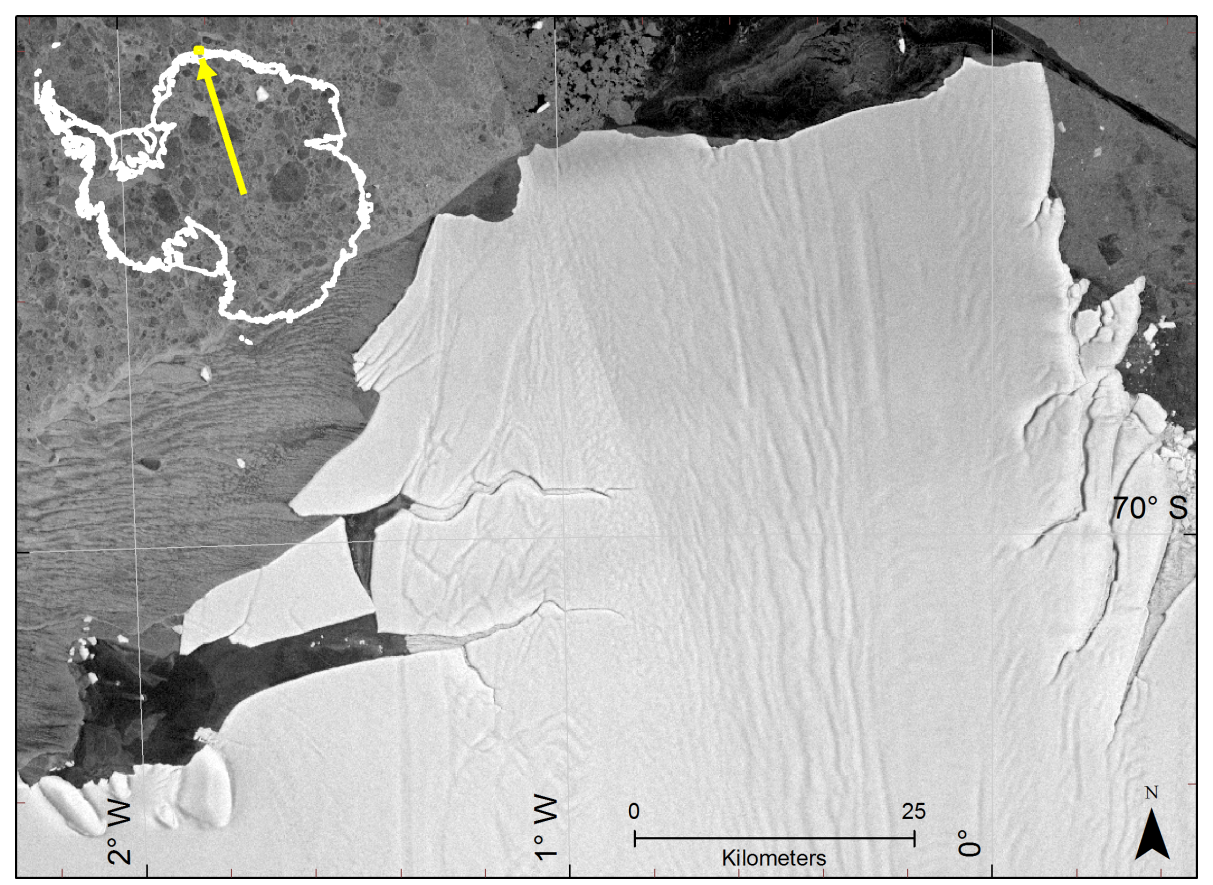

Figure 8. Icebergs calved from a parallel crevassed coastline. The SAR image shows the Fimbul Ice Shelf. In the upper right the location of this area (yellow rectangle) is indicated. The white lines in the inset image represent the coastline taken from RAMP AMM-1 (http://bprc.osu.edu/rsl/radarsat/data/) and the grounding line taken from Haran et al. [23]. Image courtesy: Byrd Polar Research Center \& CSA.

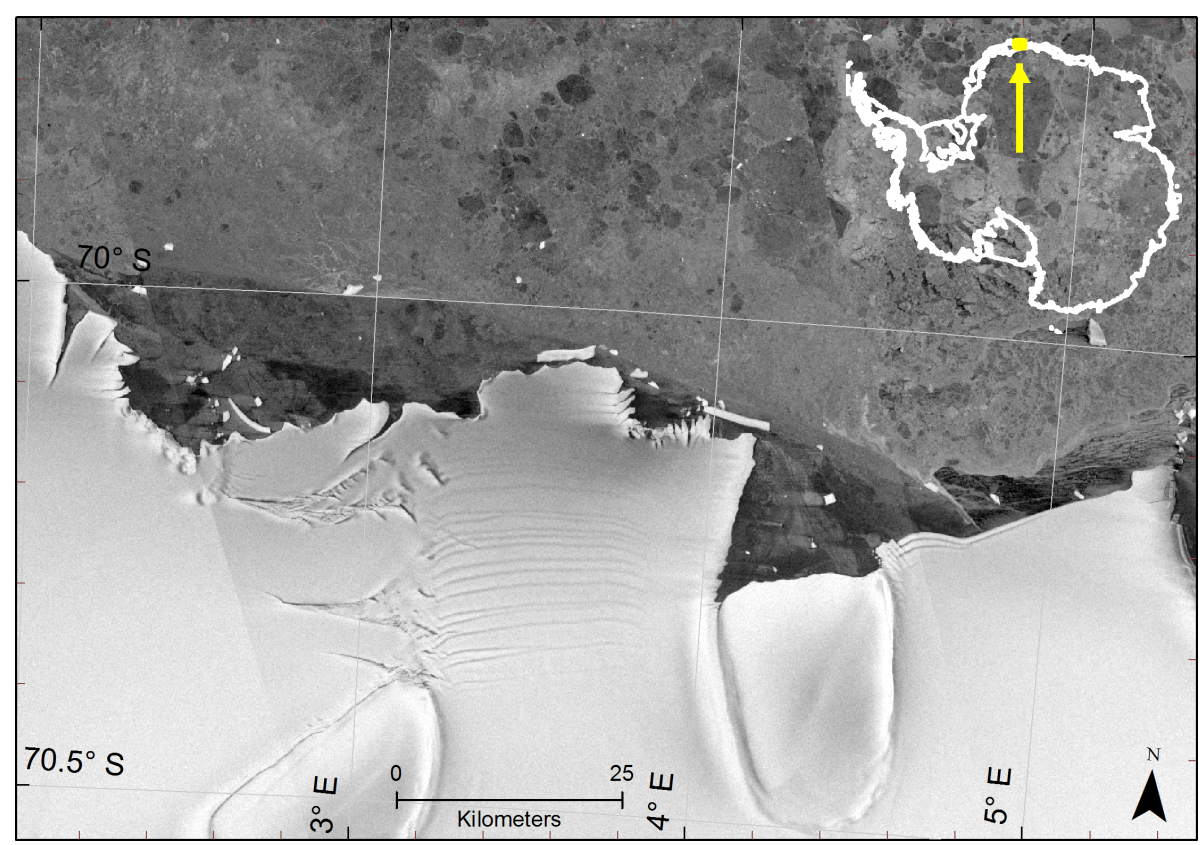


Icebergs that calve from ice fronts with parallel crevasses are of an almost rectangular shape (Figure 8-Fimbul Ice Shelf). Their width depends on the distance of the fractures at the calving front. A prominent example for this case is the tabular iceberg B15. This giant iceberg-the largest observed from satellite (dimensions of $295 \mathrm{~km} \times 37 \mathrm{~km}$ [28]) — calved from the Ross Ice Shelf in March 2000 .

Figure 9. Two examples of iceberg calved from an IS pattern coastline. Image (a) shows a large number of small icebergs in front of the small ice shelves downstream the Holmes and the De Haven Glaciers and (b) shows the D15 iceberg in front of the West Ice Shelf. In the lower right of each image the location of this area (yellow rectangles) is indicated. The white lines in the inset images represent the coastline taken from RAMP AMM-1 (http://bprc.osu.edu/rsl/radarsat/data/) and the grounding line taken from Haran et al. [23]. Image courtesy: Byrd Polar Research Center \& CSA.

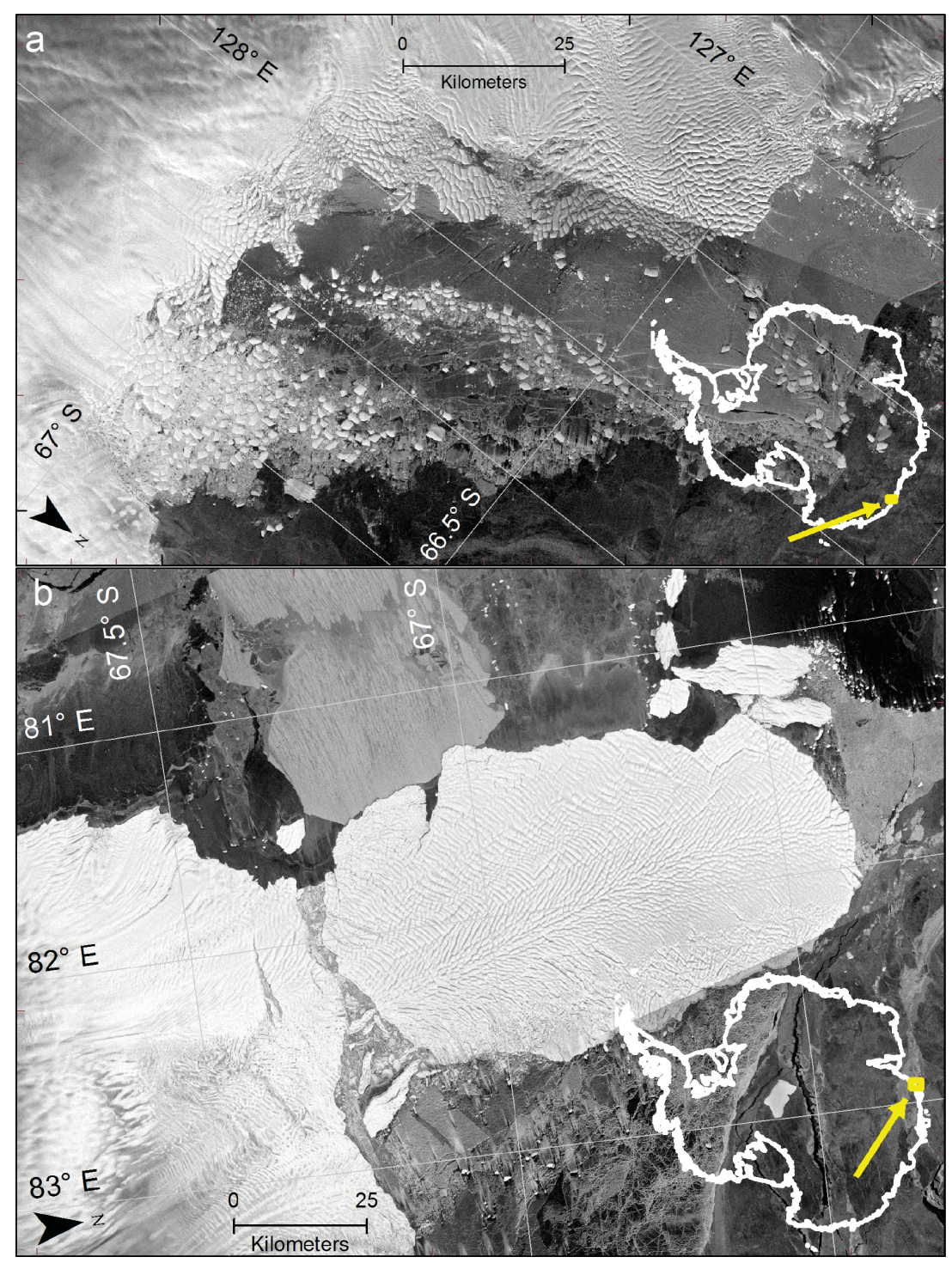

Areas of orthogonal and parallel crevasses can be found on ice shelves of any size. The IS pattern is typical for glacier tongues and smaller ice shelves (area $<15,000 \mathrm{~km}^{2}$ ) and is also present on fast flowing large ice streams (e.g., Stancomb Wills Ice Stream, which is part of the Brunt Ice Shelf). Two different kinds of iceberg shapes originate from the IS pattern. The calving type shown in Figure 9a 
is characterized by a continuous discharge of small, approximately quadratic icebergs. As an example, an image of icebergs that calved from small ice shelves in front of the Holmes and De Haven Glaciers (Pourpoise Bay, East Antarctica) is provided (Figure 9a). Another type of calving, which is common for glacier tongues reaching far out into the ocean (e.g., Mertz or Drygalski glacier tongues) is presented in Figure 9b. Large rifts propagate from the side of the glacier tongue slowly into the interior until they are joined, giving birth to a large iceberg that still carries the IS-pattern originally found on the surface of the seaward part of the ice tongue. When entering warmer ocean regions or rough seas, such giant icebergs potentially disintegrate along the pre-existing fractures into smaller bergs and fragments as shown in Figure 9a. This was observed for the iceberg B10-A, which calved from the Thwaites ice tongue in 1992 [37]. An optical Landsat 7 image shows the disintegration of the originally large iceberg into smaller bergs (http://earthobservatory.nasa.gov/IOTD/view.php?id=469 assessed on 31 July 2013).

Using Table 2 one can see, which coastline class is dominant in the sectors. In sector A the grounded ice portions (C5) are the largest class, followed by $\mathrm{C}$. This suggests, that the dominant iceberg shape is rectangular in sector $\mathrm{A}$. In sector $\mathrm{C}$, the amount if $\mathrm{C} 3$-coastlines is large, which suggests that iceberg calved in sector $\mathrm{C}$ look like the ones presented in Figure 9. In all sectors, $\mathrm{C} 1$ has a large amount on the coastline length, whereas $\mathrm{C} 2$ has a lower proportion.

\section{Conclusions}

Inspection of SAR images acquired over Antarctica revealed that surface structures of ice shelves and ice tongues can be grouped into three main classes with respect to their orientation relative to the mean stable calving front: 1. parallel, 2. orthogonal and 3. a combination of both (denoted as ice stream pattern). On most ice shelves, a dense pattern of surface structures within the grounding zone can be recognized, which is no longer visible at the ice front. This is due to the fact that crevasses can heal during their advection towards the calving front [29]. Snow accumulation is an additional parameter causing surface structures to become invisible in SAR images. Parallel surface structures (C1) are most frequently observed (28\%), followed by the IS pattern (C3; 15.7\%) and orthogonal surface structures (C2; about 9\%). Grounded ice (C5) accounts for about $40 \%$ of the total coastline length. Structure patterns are related to the geometry of the calving front relative to "pinning points". Orthogonal structures are typical for a convex shape, parallel patterns for a straight or concave shape. The structure patterns observed on the surface give useful hints about the local ice dynamics.

Each class of ice front leads to a dominant iceberg shape. Rectangular icebergs calve from parallel crevassed sites, trapezoidal icebergs from orthogonal crevasses and very small nearly quadratic icebergs originate from ice shelves or tongues with IS patterns. It is observed that large icebergs that show an obvious IS-pattern at the surface are mainly calved from glacier tongues. The results presented here make it possible to confine the locations of potential calving sites of observed icebergs, in particular in combination with known drift patterns (e.g., [38]). When the origin of detected icebergs is known, their thickness at the time of calving can be determined from maps of ice shelf thickness, which leads to an improved estimation of freshwater fluxes in the Southern Ocean. 


\section{Acknowledgments}

The authors thank M. Ebner for his contributions to this work. The SAR mosaic was provided by the Byrd Polar Research Center at the Ohio State University (http://bprc.osu.edu/rsl/radarsat/data/). C. Wesche is funded by the German Research Foundation (DFG) Priority Programme 1158 "Antarctic research with comparative investigations in Arctic ice areas" (WE 4772/1). D. Jansen is funded by the HGF junior research group "The effect of deformation mechanism for ice sheet dynamics" (VHNG 802). We thank the three anonymous reviewers for constructive and helpful comments.

\section{Conflicts of Interest}

The authors declare no conflict of interest.

\section{References}

1. Paterson, W. The Physics of Glaciers, 3 ed.; Butterworth Heinemann: Oxford, UK, 1994; p. 480.

2. Jacobs, S.S.; Hellmer, H.H.; Doake, C.S.M.; Jenkins, A.; Frolich, R.M. Melting of ice shelves and the mass balance of Antarctica. J. Glaciol. 1992, 38, 375-387.

3. Benn, D.I.; Warren, C.R.; Mottram, R.H. Calving processes and the dynamics of calving glaciers. Earth Sci. Rev. 2007, 82, 143-179.

4. Rignot, E.; Jacobs, S.S.; Mouginot, J.; Scheuchl, B. Ice-shelf melting around Antarctica. Science 2013, 341, 266-270.

5. Depoorter, M.A.; Bamber, J.L.; Griggs, J.A.; Lenaerts, J.T.M.; M., L.S.R.; van den Broecke, M.R.; Moholdt, G. Calving fluxes and basal melt rates of Antarctic ice shelves. Nature 2013, 502, 89-92.

6. Oerter, H.; Kipfstuhl, J.; Determann, J.; Miller, H.; Wagenbach, D.; Minikin, A.; Graf, W. Evidence for basal marine ice in the Filchner-Ronne Ice Shelf. Nature 1992, 358, 399-401.

7. Craven, M.; Allison, I.; Fricker, H.A.; Warner, R. Properties of a marine ice layer under the Amery Ice Shelf, East Antarctica. J. Glaciol. 2009, 55, 717-728.

8. Pattyn, F.; Matsuoka, K.; Callens, D.; Conway, H.; Depoorter, M.; Docquier, D.; Hubbard, B.; Samyn, D.; Tison, J.L. Melting and refreezing beneath Roi Baudouin Ice Shelf (East Antarctica) inferred from radar, GPS, and ice core data. J. Geophys. Res. 2012, 117, 1-8.

9. Jansen, D.; Luckman, A.; Kulessa, B.; Holland, P.R.; King, E.C. Marine ice formation in a suture zone on the Larsen C Ice Shelf and its influence on ice shelf dynamics. J. Geophys. Res. 2013, $118,1-13$.

10. Silva, T.A.M.; Bigg, G.R.; Nicholls, K.W. Contribution of giant icebergs to the Southern Ocean freshwater flux. J. Geophys. Res. 2006, 111, 1-8.

11. Jansen, D.; Schodlok, M.; Rack, W. Basal melting of A-38B: A physical model constrained by satellite observations. Remote Sens. Environ. 2007, 111, 195-203.

12. Holt, T.O.; Glasser, N.F.; Quincey, D.J.; Siegfried, M.R. Speedup and fracturing of George VI Ice Shelf, Antarctic Peninsula. The Cryosphere 2013, 7, 797-816.

13. Glasser, N.F.; Scambos, T. A structural glaciological analysis of the 2002 Larsen B ice-shelf collapse. J. Glaciol. 2008, 54, 3-16.

14. Sergienko, O. Basal melt channels on ice shelves. J. Geophys. Res. 2013, 118, 1-14. 
15. Luckman, A.; Jansen, D.; Kulessa, B.; King, E.; Sammonds, P.; Benn, D. Basal crevasses in Larsen C Ice Shelf and implications for their global abundance. The Cryosphere 2012, 6, 113-123.

16. McGrath, D.; Steffen, K.; Scambos, T.; Rajaram, H.; Casassa, G.; Lagos, J.R. Basal crevasses and associated surface crevassing on Larsen C Ice Shelf, Antarctica, and their role in ice-shelf instalbility. Ann. Glaciol. 2012, 58, 10-14.

17. Humbert, A.; Steinhage, D. The evolution of the western rift area of the Fimbul Ice Shelf, Antarctica. The Cryosphere 2011, 5, 931-944.

18. Dowdeswell, J.A. On the nature of Svalbard icebergs. J. Glaciol. 1989, 35, 224-234.

19. Jezek, K.; Sohn, H.; Noltimier, K. The Radarsat Antarctic Mapping Project. In Proceedings of 1998 IEEE International Geoscience and Remote Sensing Symposium Proceedings, IGARSS '98, Seattle, WA, USA, 6-10 July 1998; Volume 5, pp. 2462-2464.

20. Oliver, C.; Quegan, S. Understanding Synthetic Aperture Radar Images; Artech House: Boston, MA, USA, 1998; p. 479.

21. Septhon, A.; Brown, L.; Macklin, J.T.; Partington, K.C.; Veck, N.; Rees, W. Segmentation of Synthetic-Aperture Radar imagery of sea ice. Int. J. Remote Sens. 1994, 15, 803-825.

22. Young, N.W.; Turner, D.; Hyland, G.; Williams, R.N. Near-coastal iceberg distribution in East Antartica, 50-145². Ann. Glaciol. 1998, 27, 68-74.

23. Haran, T.; Bohlander, J.; Scambos, T.; Painter, T.; Fahnestock, M. MODIS Mosaic of Antarctica (MOA) Image Map; National Snow and Ice Data Center: Boulder, CO, USA, 2005.

24. Rees, W.G. Remote Sensing of Snow and Ice; Taylor \& Francis: Boca Raton, FL, USA, 2006.

25. Wesche, C.; Dierking, W. Iceberg signatures and detection in SAR images in two test regions of the Weddell Sea, Antarctica. J. Glaciol. 2012, 58, 325-339.

26. Lopes, A.; Touzi, R.; Nezry, E. Adaptive speckle filters and scene heterogeneity. IEEE Trans. Geosci. Remote Sens. 1990, 28, 992-1000.

27. Willis, C.J.; Macklin, J.T.; Partington, K.C.; Teleki, K.A.; Rees, W.G.; Williams, R.G. Iceberg detection using ERS-1 Synthetic Aperture Radar. Int. J. Remote Sens. 1996, 17, 1777-1795.

28. Lazzara, M.A.; Jezek, K.C.; Scambos, T.A.; MacAyeal, D.R.; van der Veen, C.J. On the recent calving of icebergs from the Ross ice shelf. Polar Geogr. 2008, 31, 15-26.

29. Derradji-Aouat, A.; Evgin, E. A constitutive model for isotropic freshwater ice. Can. Geotech. J. 2001, 38, 818-827.

30. Mouginot, J.; Scheuchl, B.; Rignot, E. Mapping of ice motion in Antarctica using Synthetic Aperture Radar data. Remote Sens. 2012, 4, 2753-2767.

31. Rignot, E.; Mouginot, J.; Scheuchl, B. MEaSUREs InSAR-Based Antarctica Ice Velocity Map; National Snow and Ice Data Center: Boulder, CO, USA, 2011.

32. Lenaerts, J.T.M.; van den Broecke, M.R.; van de Berg, W.J.; van Meijgaard, E.; Munneke, P.K. A new, high-resolution surface mass balance map of Antarctica (1979-2010) based on regional atmospheric climate modeling. Geophys. Res. Lett. 2012, 39, 1-5.

33. Glasser, N.F.; Gudmundsson, G. Longitudinal surface structures (flowstripes) on Antarctic glacier. The Cryosphere 2012, 6, 383-391.

34. Hughes, T. On the disintegration of ice shelves: The role of fracture. J. Glaciol. 1983, 29, 98-117. 
35. Bassis, J.; Fricker, H.A.; Coleman, R.; Minster, J.B. An investigation into the forces that drives ice-shelf rift propagation on the Amery Ice Shelf, East Antarctica. J. Glaciol. 2008, 54, 17-27.

36. Fricker, H.A.; Young, N.W.; Allison, I.; Coleman, R. Iceberg calving from the Amery Ice Shelf, East Antarctica. Ann. Glaciol. 2002, 34, 241-246.

37. Stephen, H.; Long, D. Study of Iceberg B10A Using Scatterometer Data. In Proceedings of IEEE 2000 International Geoscience and Remote Sensing Symposium, Honolulu, HI, USA, 24-28 July 2000; pp. 1340-1342.

38. Gladstone, R.M.; Bigg, G.R.; Nicholls, K.W. Iceberg trajectory modeling and meltwater injection in the Southern Ocean. J. Geophys. Res. 2001, 106, 19903-19915.

(c) 2013 by the authors; licensee MDPI, Basel, Switzerland. This article is an open access article distributed under the terms and conditions of the Creative Commons Attribution license (http://creativecommons.org/licenses/by/3.0/). 